\title{
Corrective Approach in a Rare Case of Isolated Lipomyelomemingocele before First birthday celebration.
}

\author{
Dr. Tanushree Mondal ${ }^{1}$, Dr. Himel Bera ${ }^{2}$, Dr. Koushik Dewan ${ }^{3}$ \\ ${ }^{I}$ (Assistant Professor, Department of Community Medicine and Assistant Director of Medical Education, \\ Directorate of Medical Education, Department of Health \& Family Welfare, Salt Lake, Swasthya Bhawan, \\ Kolkata-91, India) \\ 2 (Demonstrator, Department of Pathology, Medical College, Kolkata-73, India)) \\ ${ }_{3}^{3}$ (Demonstrator,Department of Laboratory Medicine,School of Tropical Medicine,Kolkata-73,India)
}

\section{Introduction}

Lipomyelomeningocele is basically a closed spinal dysraphism which has no exposed neural tissue. ${ }^{1}$ Myelomeningocele occurs due to primary neurulation defects or due to closure of posterior neuropore which occurs 17 and 26 post ovulatory days simultaneously. Lipomyelomeningocele is the most common fate of premature disjunction. ${ }^{2}$ Tethered cord is inherently associated with lipomyelomeningocele. This rare entity has been noticed in 0.3 per 10,000 live birth. ${ }^{3,4,5,6}$ Here we got an eight month old baby with gradually increasing back lump, with a provisional diagnosis of lipoma, sacrococcygeal teratoma or any malignant soft tissue tumour. Ultimtely we successfully diagnosed this rare entity after a battery of investigation and rendered appropriate timely management leading to disease free survival of the baby.

\section{CASE REPORT}

An eight month old female child from Muslim community presented at our outpatient department with her mother with a complaint of gradually increasing lump on her back. On palpation was the lump over the lumbosacral region was soft in consistency without any neurodeficit. It was present since birth without any history of exsanguinations. No family history was present. Axial plane CT scan was done by taking $3 \mathrm{~mm}$ thin parallel slices from L1 to S1. CT finding depicted a large fatty mass is herniating through defect in posterior element of L5 and sacral vertebrae. Large bone formation was noted in left paramedial gluteal region. Epidural fat \& dural sac were normal. CT scan of lumbar spine suggested large lipomeningocele with osseous dysraphic hamartoma. CT guided FNA smears revealed mature fat cells along with blood, so it was inconclusive. Subsequently1.5Tesla MRI revealed there was spinal dysraphism with a well defined T1 hyperintense lesion outside the dura \& continuous with subcutaneous fat from L3-4 level. (Fig.1 a \& b)There was low lying spinal cord extending up to L4 vertebral body which was continuous dorsally with the neural placode . Nerve roots arises from neural placode, crossed the subarachnoid space \& met their exit from the spinal canal. There was widening of spinal canal. No abnormal focal altered signal was seen in vertebra. Intervertebral discs showed normal signal. Sagittal screening did not revealed any abnormality in cranio vertebral junction .The above described features likely to represent a case of lipomyelomeningocele at lumbosacral region. Though the patient was asymptomatic till then even; considering future neurodeficit, bowel bladder dysfunction -a corrective neurosurgical approach was planned by neurosurgeon. Total mass was removed with correction of lumbosacral fascia with releasing filum terminale. Histopathological examination of the mass showed that it was an admixture of mature fat cells, myloid component covered by meningeal sheath. (Fig.2 \& 3) Ultimately clinical findings were confirmed by biopsy. After four months of operation post operative patient was doing well without any complication like CSF leakage, wound infection ,neural deficit or rmeningitis. ${ }^{7}$

\section{DISCUSSION}

Though it was an isolated finding devoid of any other deformity even then we thoroughly gathered family history and mother's folic acid intake during pregnancy; but did not encounter anything significant. Fortunately though our patient was clinically asymptomatic alike the case described by Hertzler et al study ${ }^{8}$ we did an USG whole abdomen to rule out postvoid residual urine stasis and any other congenital defect ${ }^{9}$.Though 3D USG helped in achieving the prenatal diagnosis but MRI is the investigation of choice in postnatal counterpart and making operative decision in conjunction with postoperative followup. ${ }^{10}$ 

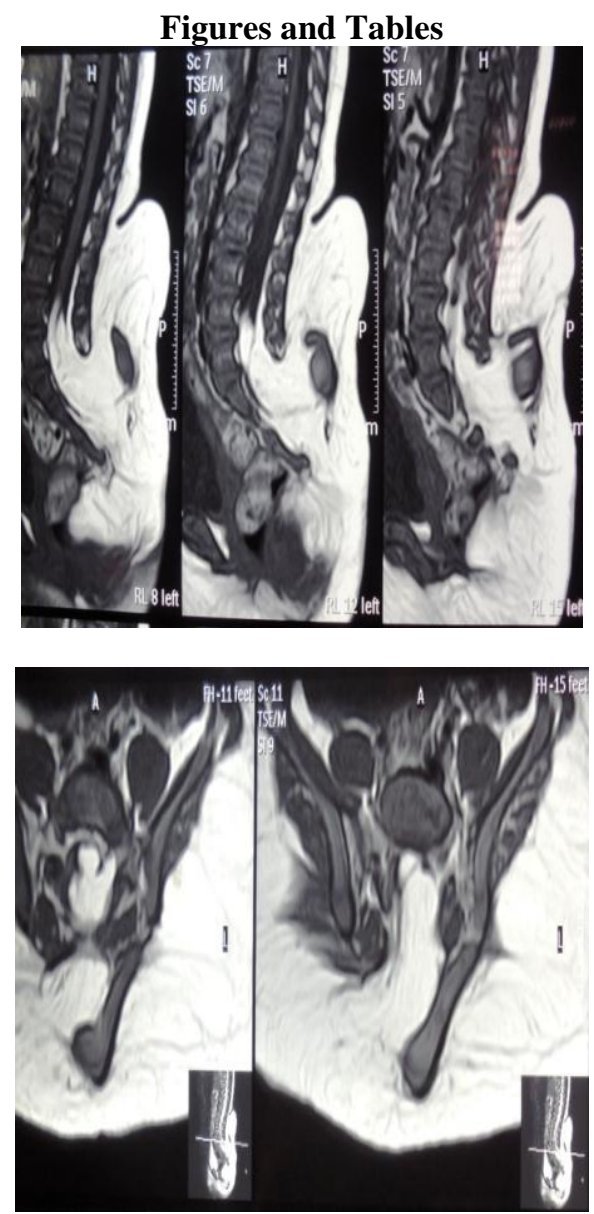

Fig 1 a (sagittal) \&b (coronal) sections in MRI showing hyper intense lesion which is outside the dura \& continuous with subcutaneous fat from L3-4 level.

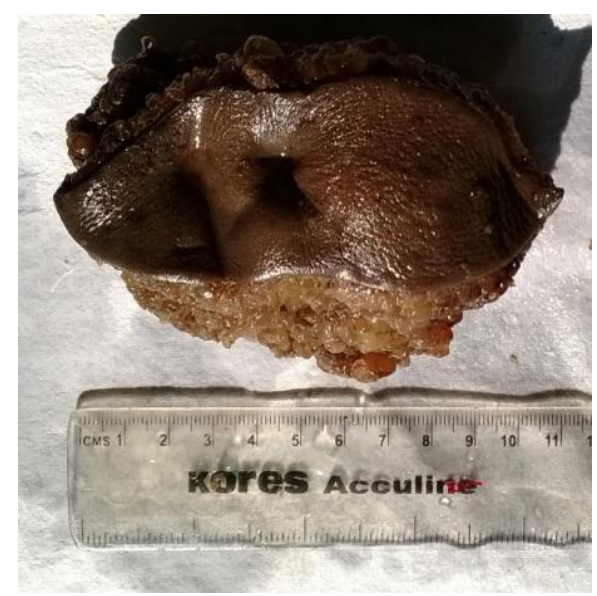

2.Gross photograph of mass

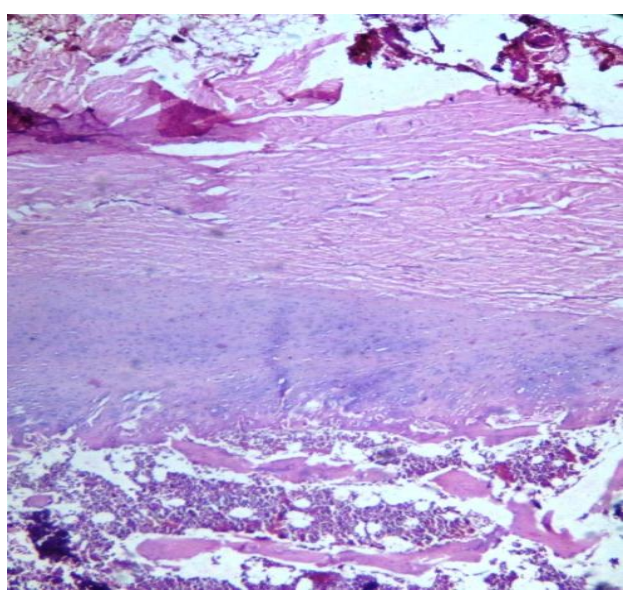

3.Microphotograph of lipomyelomeningocele(100x,H\&E)

\section{CONCLUSION}

Though there are controversies ${ }^{11,12}$ regarding the actual time of operation we stage the patient earliest in order to achieve a disease free survival before appearance of any symptom. And also there is an logarithmic association with age and neurodeficit either due to increased stretch on the spinal cord with axial growth spurts ${ }^{13,14,15,16}$ or due to the upward movement of the conus medullaris during the axial growth. ${ }^{17}$ Considering all these things on the aspect of treating such rare congenital anomaly we got calculated result till now. 


\section{REFERENCES}

[1] Arai H, Sato K, Okuda O, Miyajima M, Hishii M, Nakanishi H, et al: Surgical experience of 120 patients with lumbosacral lipomas. Acta Neurochir (Wien) 143:857-864, 2001

[2] Warder DE: Tethered cord syndrome and occult spinal dysraphism. Neurosurg Focus 10(1):e1, 2001

[3] Agopian AJ, Canfield MA, Olney RS, Lupo PJ, Ramadhani T, Mitchell LE, et al: Spina bifida subtypes and sub-phenotypes by maternal race/ethnicity in the National Birth Defects Prevention Study. Am J Med Genet A [epub ahead of print], 2011

[4] De Wals P, Van Allen MI, Lowry RB, Evans JA, Van den Hof MC, Crowley M, et al: Impact of folic acid food fortification on the birth prevalence of lipomyelomeningocele in Canada. Birth Defects Res A Clin Mol Teratol 82:106-109, 2008

[5] Forrester MB, Merz RD: Descriptive epidemiology of lipomyelomeningocele, Hawaii, 1986-2001. Birth Defects Res A Clin Mol Teratol 70:953-956, 2004

[6] McNeely PD, Howes WJ: Ineffectiveness of dietary folic acid supplementation on the incidence of lipomyelomeningocele: pathogenetic implications. J Neurosurg 100 (2 Suppl Pediatrics): 98-100, 2004

[7] Kanev PM, Lemire RJ, Loeser JD, Berger MS: Management and long-term follow-up review of children with lipomyelomeningocele, 1952-1987. J Neurosurg 73:48-52, 1990

[8] Hertzler DA II, DePowell JJ, Stevenson CB, Mangano FT: Tethered cord syndrome: a review of the literature from embryology to adult presentation. Neurosurg Focus 29(1):E1, 2010

[9] Cochrane DD: Cord untethering for lipomyelomeningocele: expectation after surgery. Neurosurg Focus 23(2):E9, 2007

[10] Bulas D: Fetal evaluation of spine dysraphism. Pediatr Radiol 40:1029-1037, 2010

[11] Cochrane DD, Finley C, Kestle J, Steinbok P: The patterns of late deterioration in patients with transitional lipomyelomeningocele. Eur J Pediatr Surg 10 (Suppl 1):13-17, 2000

[12] Kulkarni AV, Pierre-Kahn A, Zerah M: Conservative management of asymptomatic spinal lipomas of the conus. Neurosurgery 54:868-875, 2004

[13] Hoffman HJ, Hendrick EB, Humphreys RP: The tethered spinal cord: its protean manifestations, diagnosis and surgical correction. Childs Brain 2:145-155, 1976

[14] Hoffman HJ, Taecholarn C, Hendrick EB, Humphreys RP: Management of lipomyelomeningoceles. Experience at the Hospital for Sick Children, Toronto. J Neurosurg 62:1-8, 1985

[15] Kanev PM, Bierbrauer KS: Reflections on the natural history of lipomyelomeningocele. Pediatr Neurosurg 22:137-140, 1995

[16] Ohe N, Futamura A, Kawada R, Minatsu H, Kohmura H, Hayashi K, et al: Secondary tethered cord syndrome in spinal dysraphism. Childs Nerv Syst 16:457-461, 2000

[17] Huang SL, Shi W, Zhang LG: Surgical treatment for lipomyelomeningocele in children. World J Pediatr 6:361-365, 2010 